\title{
ANALISIS DAMPAK PENAMBANGAN PASIR BERBASIS PEMBANGUNAN BERKELANJUTAN DI KECAMATAN NGEBEL KABUPATEN PONOROGO
}

\author{
Ardhyan Dwi Nurcahyo, Muzayanah \\ Program Magister Pendidikan Geografi, Sekolah Pascasarjana, UNESA,
}

\begin{abstract}
Abstrak: Industri pertambangan merupakan industi potensial yang selalu diandalkan pemerintah Indonesia dalam memperoleh keuntungan akan tetapi Industri pertambangan mempunyai dampak positif dan negatif. Penambangan pasir mempunyai peran penting terhadap ekonomi dan sosial masyarakat sekitar Desa Ngrogung namun kegiatan penambangan pasir belum melakukan konsep keberlangsungan. Oleh sebab itu perlunya analisis mengenai dampak penambang pasir berbasis Pembangunan berkelanjutan di Penambangan pasir Desa Ngrogung. Jenis penelitian yang digunakan adalah penelitian kualitatif dengan menggunakan teknik analisis deskriptif. Hasil penelitian menunjukan terjadinya dampak positif dan dampak negatif. Pada bidang ekonomi terjadi pengaruh positif peningkatan pendapatan pada masyarakat disekitar penambangan pasir, Pada bidang sosial terjadi pengaruh positif terjadi peningkatan penyerapan tenaga kerja pada kegiatan penambangan, terjadi penyusutan kemiskinan dampak negatif masih banyak masyarakat yang bekerja pada lokasi penambangan yang tidak memakai standar kesehatan dan keselamatan. Pada bidang lingkungan terjadi pengaruh polusi air, Polusi udara serta terjadi degradasi lahan sehingga berpotensi terjadi bencana tanah longsor.
\end{abstract}

Kata kunci : Pembangunan berkelanjutan, Penambangan

Abstract: The mining industry is an industry potential that is always relied on in every government in Indonesia to get profits, but the mining industry has positive and negative impacts. Sand mining can play an important role in the economy and the community around Ngrogung Village. However, sand mining activities have not carried out the concept of sustainability. Therefore it is necessary to analyze the impact of sand mining based on sustainable development in sand mining in Ngrogung Village. This type of research used qualitative by using descriptive analysis techniques. The results of the study show a positive impact and a negative impact. In the economic field, there is an increase in the effect of increasing income on the community around the sand mining $c$. In the social sector, the positive effect is an increase in labor absorption in mining activities, there is a reduction in poverty, a negative impact, there are still many people who work at mining locations that do not use health standards and safety. In the environmental sector there is the influence of air pollution, air pollution and degradation events that occur landslides disaster.

Keywords: Sustainable development, mining.

\section{A. PENDAHULUAN}

Industri

pertambangan

merupakan industri potensial yang selalu diandalkan di setiap

pemerintahan di Indonesia untuk

menghasilkan keuntunggan berupa

Alamat korespondensi :

E-mail : ardyandn@gmail.com 
Devisa. Dampak positif selain mendapatkan devisa juga mempunyai manfaat dalam penyerapan tenaga kerja di Pemeritahan Kabupaten maupun Pemerintah Kota.

Industri petambangan yang mempunyai dampak positif pertambahan devisa dan penyerapan tenaga kerja juga mempuyai dampak negatif yaitu terjadinya degradasi lingkungan dan pencemaran disekitar area pertambangan. Sering kali dijumpai penambangan mempunyai izin atau tanpa izin. Meskipun pada kedua penambangan akan berdampak pada kerusakan lingkungan. Terdapat beberapa perbedaan pada penambangan berizin yaitu masih terdapat tanggung jawab akibat proses penambangan, Hal ini berbeda dengan penambangan tanpa izin yang tidak bertanggung jawab dari kerusakan lingkungan.

Dampak Penambangan pasir diperkuat dengan Definisi Kerusakan lingkungan, yang tulis J. M. Johnson dan J. Baros (dalam Purwanto, 2018), terjadinya kerusakan lingkungan terdapat hubungan erat dengan kegiatan manusia aktivitas yang dilakukan yaitu pembangunan, kegiatan industri, dan pertanian. Kajian teori ini mempunyai kesamaan dengan definisi teori yang diungkapkan oleh munasinghe (dalam purwanto, 2018) dalam kajiannya interaksi yang terjadi karena adanya hubungan manusia dan lingkungan tidak bisa dihindarkan pada proses pembangunan berkalnjutan.

Pada konsep pembangunan berkelajutan terdapat 3 komponen utama yang harus dipertimbangkan yaitu Ekonomi, Sosial dan Lingkungan. 3 komponen utama ini harus mempunyai keseimbangan, tidak boleh mengalami ketimpangan antara komponen lainya. Tidak hanya itu penambangan illegal berdampak pada keselamatan pekerja tambang karena kurangnya pengetahuan keselamatan kerja pada Proses penambangan.

Kewajiban melestarikan dan menjaga lingkungan yang tidak dipenuhi dalam proses penambangan hal ini tidak sesuai dengan peraturan Kewajiban memelihara lingkungan. Kewajiban tersebut telah tertuang sebelumnya dalam UUPLH 1997 yang kemudian disempurnakan dalam UUPPLH 2009, yang tertuang dalam Pasal 67 yang menyatakan bahwa "setiap orang berkewajiban memelihara kelestarian fungsi lingkungan hidup serta mengendalikan pencemaran dan/atau kerusakan lingkungan hidup.

Industri Pertambangan Identik dengan penghasil komoditas seperti Bauksit, Tembaga, Emas, Nikel dan Batu bara. Di dalam hasil bahan galian sudah digolongkan menjadi 3 golongan menurut UU No 11 Tahun 1967 yang 
kemudian diubah menjadi UU No 4 tahun 2009 Bahan Galian pertambangan terdapat 3 Golongan yaitu Golongan A : Bahan Galian Strategis, Dapat didefiniskan untuk membantu bidang perekonomian Negara contoh : Minyak Bumi, Gas dan Batu bara ; Bahan galian golongan B : Bahan galian mempunyai skala vital, vital dapat didefinisikan bahan galian yang menyangkut hajat hidup orang banyak contoh : Emas, Perak dan Tembaga; Bahan galian golongan $\mathrm{C}$ : bahan galian yang mempunyai sifat vital dan strategis contoh : Tanah liat, Batu kapur dan Pasir .

Pemanfaatan bahan galian golongan $\mathrm{A}, \mathrm{B}$ dan $\mathrm{C}$ secara maksimal dimasyarakat adalah bahan galian golongan $\mathrm{C}$ yang berupa pasir karena pada dasarnya bahan pasir mampunyai jumlah yang melimpah. Ditinjau dari pemanfaatan jangka pendek maupun jangka panjang, bahan pasir akan mengalami penyusutan jumlah akibat pemanfaatan yang berlebihan akibat dari kebutuhan pasir yang tinggi untuk kegiatan pembangunan yang setiap tahunya pembangunan mengalami peningkatan.

Akibat belum maksimal diterapkannya konsep pembangunan berkelanjutan dan ketidak pedulian para penambang pada peningkatan kelestarian lingkungan. Hal ini diperkuat dengan hasil penelitian
LPPM Universitas Muhammadiyah Ponorogo tahun 2015 yang mendapatkan hasil akibat pertambangan pasir trass di Desa Ngrogung Kecamata Ngebel Kabupaten Ponorogo mempunyai Indikasi adanya kebocoran air telaga ngebel yang berpotensi terjadinya becana tanah longsor.

Konsep Pembangunan Bekelanjutan dapat digunakan sebagai salah satu pedoman dalam proses perencanaan kegiatan pertambangan. Pertambangan yaitu suatu kegiatan yang dilakukan dengan penggalian ke dalam tanah (bumi) untuk mendapatkan sesuatu yang berupa hasil tambang menurut Supramono (2012)

Pertambangan menurut UU No.4 Tahun 2009 Undang-Undang Pertambangan Mineral dan Batubara (UUPMB), pasal 1 yaitu sebagian atau seluruh tahapan kegiatan dalam rangka penelitian, pengolahan dan pengusahaan mineral atau batu bara yang meliputi penyelidikan umum, eksplorasi, studi kelayakan konstruksi, penambangan, pengolahan dan pemurnian, pengangkutan dan penjualan, serta kegiatan pasca tambang.

Salim (1990) menyatakan Konsep Pembangunan Berkelajutan memiliki tujuan untuk dapat 
meningkatkan kesejahteraan masyarakat dan untuk mencukupi kebutuhan-kebutuhan

dan menampung aspirasi manusia. Konsep pembangunan berkelanjutan pada dasarnya diperuntukan untuk menemukan solusi pemerataan keadilan generasi masa kini dan generasi masa yang akan datang.

Menurut

Kementrian

Lingkungan hidup (KLH) 1990) pembangunan yang mempunyai dasar lebih berorientasi ekonomi, dapat diketahui keberlanjutannya dengan cara diukur berdasarkan tiga kriteria yaitu : (1) Tidak terjadi pemborosan penggunaan sumber daya alam atau depletion of natural resources;(2) Tidak ada polusi dan dampak lingkungan lainnya; (3) kegiatannya harus dapat meningkatkan useable resources ataupun replaceable resource.

Brundtland (1987) Menyatakan bahwa konsep pembangunan berkelanjutan merupakan sebuah proses yang mempunyai dasar "Dalam memenuhi kebutuhan konsumsi masa sekarang tanpa mengurangi kebutuhan generasi masa depan" Salah satu dari beberapa faktor yang harus dilalui dalam terciptanya pembangunan berkelanjutan adalah mencari solusi dalam memperbaiki degradasi lingkungan tanpa mengurangi kebutuhan pembangunan ekonomi dan keadilan ekonomi

UU No. 32 Tahun 2009 mengenai Perlindungan dan Pengelolaan Lingkungan Hidup, Menyatakan bahawa pengertian dari pembangunan berkelanjutan diartikan sebagai upaya sadar dan terencana yang memadukan aspek lingkungan hidup, sosial, dan ekonomi ke dalam strategi pembangunan untuk menjamin keutuhan lingkungan hidup serta keselamatan, kemampuan, kesejahteraan, dan mutu hidup generasi masa kini dan generasi masa depan.

Penerapan konsep dan model
yang berbeda oleh beberapa ahli
tentang pembangunan berkelanjutan
untuk pertambangan pasir digambarkan
dan dianalisis melalui studi literatur,
sehingga dapat ditemukan hasil yang
sesuai dengan harapan dan tercapainya
tujuan penulisan artikel ini.
Proses degradasi lingkungan
akibat dari Pertambangan Pasir di
Kecamatan Ngebel harus
mempertimbangkan kelangsungan
Lingkungan, Ekonomi dan Sosial
sehinggga kualitas lingkungan bisa terus

Penerapan konsep dan model li 
berkelanjutan, ekonomi sekitar pertambangan mempunyai potensi jangka panjang dan tidak adanya konflik sosial disekitar area pertambangan sehingga tidak menimbulkan kerugiatan atau kerusakan dimasa yang akan dating akibat proses pertambangan. Perlu analisis dampak pertambangan pasir berbasis pembangunan berkelanjutan sehingga dapat diketahui dampak yang ditimbulkan dari proses pertambangan pasir di Kecamatan Ngebel Kabupaten Ponorogo. Alasan Pemilihan pertambangan pasir di Kecamatan Ngebel karena berlokasi dekat dengan tempat pariwisata unggulan yang berpotensi menambah devisa daerah dari bidang pariwisata

Peneliti mengambil rumusan masalah:

a. Bagaimana dampak lingkungan pertambangan pasir berbasis pembangunan berkanjutan dikecematan ngebel?

b. Bagaimana dampak sosial-ekonomi masyarakat disekitar pertambangan pasir ?

Berdasarkan latar belakang di atas maka penulis melakukan penelitian dengan judul "Analisis Dampak Penambangan Pasir Berbasis Pembangunan Berkelajutan di Desa Ngrogung Kecamatan Ngebel Kabupaten Ponorogo" dengan tujuan untuk mengetahui Dampak Lingkungan, akibat penambangan pasir berbasis pembangunan berkalnjutan dan untuk mengetahui dampak sosial ekonomi terhadap masyarakat sekitar area pertambangan.

\section{B. METODE}

Jenis penelitian yang digunakan adalah penelitian deskriptif dengan pendekatan kualitatif. Penelitian ini dilaksanakan di wilayah Kecamatan Ngebel, Kabupaten Ponorogo. Area penelitian ini adalah lahan penambangan pasir di yang terletak di Desa Ngrogung. Teknik pengumpulan data yang digunakan yaitu observasi dan wawancara. Teknik observasi digunakan untuk memperoleh data terkait luas lahan tambang dan data kualitas udara. Teknik wawancara digunakan untuk mendapatkan data sosial seperti pendapat dari masyarakat sekitar lokasi tambang. Teknik analsis data adalah analisis deskiptif. Penjelasan dituangkan dalam bentuk deskribsi, tabel, dan gambar. Metode ini dipilih mengingat kesesuaiannya dengan tujuan dalam penelitian ini.

\section{HASIL DAN PEMBAHASAN}

Lokasi Penelitian ini berada di Desa Ngrogung Kecamatan Ngebel Kabupaten Ponorogo. 
Menurut Ayu (2015) Penambangan pasir di Desa Ngrogung Kecamatan Ngebel Kabupaten Ponorogo secara resmi terdaftar di pemerintahan provinsi pada tahun 2007. Lokasi Penambangan pasir Desa Ngrogung terletak pada jalur Wisata Telaga Ngebel .

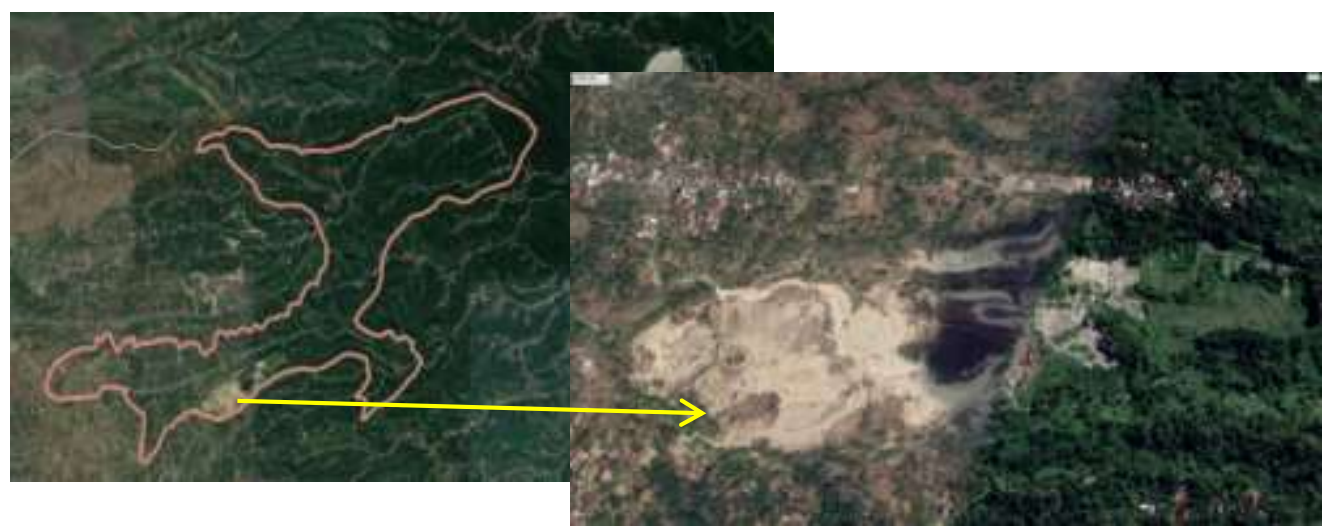

Gambar. Lokasi penambangan Desa Ngrogung (Sumber : Citra Google)

Penambangan pasir di Desa

Ngrogung pada awalnya mendapatkan respon positif terhadap masyarakat karena dengan adanya penambangan pasir menyediakan lapangan kerja dan dapat meningkatkan perekonomian masyarakat disekitar lokasi penambangan pasir, Selain berdampak pada perekonomian masyarakat dengan terdapat penambangan pasir menambah pendapatan asli daerah Kabupaten Ponorogo serta terpenuhinya kebutuhan masyarakat karena perekonomian berjalan dengan baik. Hal ini sejalan dengan hasil penelitian (Nurcahyani, 2011) yang menyatakan bahwa Kegiatan pertambangan yang terdapat di daerah terpencil minim infrastruktur dan fasilitas pendukung lainnya.

Kegiatan pertambangan dapat memberi stimulus perkembangan di wilayah tersebut. Daya dukung pemerintah yang terbatas dalam pembangunan akan terbantu dengan adanya investasi di sektor pertambangan. Dengan Tumbuhnya sektor investasi, Infrakstruktur akses informasi dan fasilitas di lokasi tambang akan berdampak baik pada kondisi sosial dan ekonomi masyarakat Desa Ngrogung Kecamatan Ngebel Kabupaten Ponorogo.

Penambangan pasir Desa 
Ngrogung Kecamatan Ngebel membawa dampak positif bagi masyarakat, Selain membawa dampak positif. Penambangan pasir Desa Ngrogung terdapat sisi Negatif pada faktor lingkungan

Masyarakat sekitar penambangan pasir terganggu dengan adanya polusi udara diakibatkan dari debu yang berlebih, polusi suara akibat dari operasional truk pembawa pasir, rusaknya jalan akses Wisata Telaga ngebel sehingga berdampak pada kenyamanan wisatawan untuk berkunjung. Berdasarkan kajian penelitian Lembaga Penelitian dan Pengabdian Masyarakat Universitas Muhammadiyah Ponorogo (LPPM) 2015 menyatakan bahwa terdapat potensi terjadinya tanah longsor .

\section{a) Dampak penambangan pasir sektor lingkungan berbasis pembangunan berkelajutan}

Berdasarakan hasil penelitian study literatur Wibowo (2016) analisis penambangan pasir berdampak pada rusaknya lingkungan. Dengan adanya kegiatan penambangan yang tidak mengunakan dasar konsep berkelanjutan berdampak negatif pada lingkungan penambangan maupun sekitar area penambangan. Dampak Negativ yang ditimbulkan adalah terjadinya potensi bencana alam. Dari hasil penelitian LPPM Universitas Muhammadiyah Ponorogo tahun 2015 potensi bencana alam di penambangan Desa Ngrogung adalah bencana tanah longsor. Selain Bencana Tanah Lonsor, Dampak Adanya penambangan pasir di lingkungan Desa Ngrogung yang sering dikeluhkan oleh masyarakat adalah terjadi polusi udara, polusi suara, polusi air dan polusi tanah.

Polusi air dapat dijelaskan bahwa Berkurangnya ketersediaan air salah satu indikator ketersediaan keadaan air adalah tanah. Sumber daya tanah sebagai unsur air berkurang karena proses penambangan . Selain pengambilan tanah terdapat juga aktivitas pencucian tanah pada penambangan. Dampak dari pencucian tanah menghasilkan limbah sehingga me air sungai yang diperuntukan untuk proses pengairan sawah menjadi tercemar oleh hasil pencucian pasir karena pada penambangan pasir tidak mempunyai pengolahan limbah air yang terstandart. 
Penambang pasir memperoleh air dengan cara melakukan boor sehingga berdampak pada terpotongnya alur air didalam tanah. Dari Pembahasan diatas bahwa Kerusakan Lingkungan dampak dari penambangan pasir yang sudah terjadi tidak bisa dicegah dan tidak bisa dikembalikan seperti semula dan dapat menyebabkan bencana tanah longsor, karena terdapat hilangnya lapisan tanah. hilangnya lapisan tanah diperparah dengan adanya proses erosi dan sebagainya.

b) Analisis Dampak Penambangan Pasir berbasis Pembangunan berkelanjutan terhadap Sosial dan Ekonomi

\section{1) Dampak penambangan pasir terhadap sosial berbasis pembangunan berkelajutan}

Berdasarkan hasil study literatur Agustina Ayu U (2015) dan Wibowo Prakoso D (2016) dampak penambangan pasir pada sektor sosial menghasilkan dampak positif dan dampak negativ pada masyarakat Desa Ngrogung. Dampak Positif berbasis pembangunan berkelanjutan terdapat partisipasi masyarakat yang dilibatkan dalam penambangan pasir. Hal ni sesuai dengan konsep pembangunan berkelanjutan menurut Jaya Askar (2004) salah satu strategi pembangunan berkelanjutan adalah dilibatkannya masyarakat pada kegiatan ekonomi. Salain partisipasi masyarakat / keterlibatan masyarakat dalam penambangan pasir, Dengan adanya penambangan pasir berdampak tercukupinya memenuhi kebutuhan rumah tangga masyarakat sekitar, sehingga dapat memerangi kemiskinan disekitar lokasi penambangan pasir.

Pengurangan kemiskinan dilihat dari banyaknya masyarakat yang terserap pada penambangan pasir. Adanya penambangan pasir mampu meningkatnya akses pendidikan dan kesehatan pada masyarakat sekitar lokasi penambangan. Dampak Negatif dari penambangan pasir berpotensi terdapat Kesenjangan sosial antara pemilik lahan dan masyarakat pekerja. Potensi adanya konflik antar masyarakat atau masyarakat dan pemerintah. Pada Potensi konflik masyarakat dan pemerintah terjadi konflik dalam perizinan usaha penambangan yang berdampak pada penutupan penambangan masyarakat. 
Pada sektor keselamatan pekerja penambangan masih kurang memenuhi standar Kesehatan dan Keselamatan Kerja (K3) dalam hal ini masih terdapat yang tidak menggunakan penutup mata dan hidung saat melakukan proses penambangan. Sebagian besar pekerja tidak melalukan standar prosedur pekerja atau SOP yang telah di tentukan dalam penambangan. Terjadinya Dampak Positif dan negatif pada sektor sosial sesuai dengan Pendekatan - pembangunan berkelanjutan menurut Jaya Askar (2004) pada keberlanjutan sosial yang menyatakan bahwa keberlanjutan sosial dilihat dari keadilan sosial, peningkatan kualitas hidup seluruh manusia.

\section{2) Dampak penambangan pasir terhadap Ekonomi berbasis pembangunan berkelajutan}

Berdasarakan hasil penelitian study literatur Agustina (2015) dan Wibowo (2016) analisis penambangan pasir sektor ekonomi berdampak signifikan terhadap ekonomi masyarakat sekitar. hal ini dilihat dari dampak adanya kegiatan penambangan pasir meningkatkan perekonomonian disekitar lokasi penambangan Desa Ngrogung.

Masyarakatdalam penambangan merasakan peningkatan pendapatan sehingga meningkatkan kualitas hidup masyarakat dibidang pendidikan maupun kesehatan. Selain peningkatan pendapatan, Dampak adanya penambangan pasir berdampak pada penyerapan tenaga kerja pada masyarakat sekitar penambangan serta pengurangan pengangguran. Tidak hanya peningkatan pendapatan masyarakat sekitar penambangan, denganadanya penambangan pasir ini berdampak pada meningkatnya perekonomian daerah sehingga berdampak signifikasn pada pembangunan Desa Ngrogung.

Berdasarakan hasil observasi kajian literatur sebelumnya proses penambangan jangka panjang pada panambangan pasir Desa Ngrogung, Mempunyai potensi terjadi kelangkaan karena diekploitasi secara berlebihan sehingga diperkiraan adkan berdampak pada berkurangnya pendapatan masyarakat serta kelanggakaan dari sumber pasir di daerah penambangan Desa Ngrogung. 
Berdasarkan

konsep

sumberdaya yang dapat diperbarui dan tidak dapat diperbarui pembuat kebijakan di daerah harus mengidentifikasi / mengklasifikasi sumber daya sebagai sumber yang terpulih, tidak terpulihkan, dan lingkungan hidup. Sumber yang terpulihkan seperti hutan dapatmemberikan manfaat secara berkelanjutan bila tidak memperlakukan produktivitas ekonomi sebagai fungsi yang pasif atau jasa yang

\section{KESIMPULAN}

1. Penambangan pasir terhadap lingkungan mengalami kerusakan lingkungan signifikan yang mempunyai dampak polusi air, polusi udara pada masyarakat dan menurut LPPM Universitas Muhammdiyah Ponorogo berpotensi bencana tanah longsor.

2. Penambangan pasir terhadap Sosial mempunyai pengaruh positif dan negatif . Dampak positif terjadi penyerapan tenaga kerja, mengurangi pengangguan dan mengurangi kemiskinan
3. Penambangan pasir terhadap Ekonomi mempunyai pengaruh positif dalam hal ini mampu meningkatkan pendapatan masyarakat sekitar dan meningkatkan pendapatan pemerinta desa setempat.

\section{DAFTAR PUSTAKA}

Agustina, Ayu Unike. 2015. Manajemen Konflik Dalam Penambangan Pasir Tass Di Desa Ngrogung Kecamatan Ngebel Kabupaten Ponorogo

Brundtland Report, 1987, Our Common Future. Oxford University Press, Oxford.

Salim, Emil. 1990, Konsep Pembangunan Berkelanjutan, Jakarta.

Jaya, Askar. 2004. Konsep Pembangunan Berkelanjutan.

Kemen LH. 1990. Peraturan Pemerintah Republik Indonesia Nomor 20 Tahun 1990 tentang Pengendalian Pencemaran Air. Jakarta : Kementerian Lingkungan Hidup Republik Indonesia

Rizki, Fitri. Analisis Dampak Lingkungan dan Sosial Ekonomi Yang Di Timbulkan Dari Aktivitas Eksplorasi 
Tambang Galian C di

Kabupaten Ponorogo.

Supramono, Gatot, Hukum

Pertambangan Mineral dan Batu

Bara di Indonesia, Jakarta,

Rineka Cipta, 2012, cet.ke-1.

Undang-Undang Nomer 4 tahun 2009

Undang-Undang Nomer 32 Tahun 2009
Undang-Undang Nomer 11 Tahun 1967

Wibowo, Prakoso D.2016.Dampak

Ekploitasi Pasir Trass

Terhadap Persepsi

Masyarakat Mengenai

Eekonomi, Sosial dan Lingkungan ( Studi Kasus di

Desa Ngrogung, Kecamatan Ngebel,

Kabupaten

Ponorogo) 